\title{
FIRST CONFIRMED RECORDS OF AGROSTIS SCABRA (POACEAE, AGROSTIDINAE) IN THE CHINESE FLORA
}

\author{
Beata Paszko \& Bing LiU
}

\begin{abstract}
The first confirmed records of Agrostis scabra Willd. are reported from a northeastern Chinese province, Jilin. This extends the native range of the species into China. The recent Flora of China does not include A. scabra. The detailed morphological characters, diagnostic comparisons and habitat are presented, along with a distribution map of $A$. scabra in East and Northeast Asia.
\end{abstract}

Key words: Agrostis clavata, Asia, distribution, misidentification, taxonomy

Beata Paszko, Department of Vascular Plant Systematics and Phytogeography, W. Szafer Institute of Botany, Polish Academy of Sciences, Lubicz 46, 31-512 Kraków, Poland; e-mail: b.paszko@botany.pl

Bing Liu, State Key Laboratory of Systematic and Evolutionary Botany, Institute of Botany, Chinese Academy of Sciences, Beijing 100093, China

\section{INTRODUCTION}

The lead author and collaborators in a series of papers have clarified numerous lower-level taxonomic issues among several Eurasian taxa of Agrostis L. (Paszko 2012, 2014b; Paszko \& Pendry 2013; Paszko \& Soreng 2013; Paszko et al. 2015), described new species (Paszko 2014a), and published new records (Nobis et al. 2014, 2016). Recently the first author located eight duplicates (KUN, PE) representing four separate collection events of Agrostis, incorrectly identified as A. clavata Trin. or else unidentified. They were collected from the vicinity of Mt. Changbai in China's northeastern Jilin Province; the Changbai mountain range is located on the border between China and North Korea. A detailed examination showed that they represent $A$. scabra Willd.

\section{MATERIAL AND METHODS}

We studied specimens in KUN, P and PE (Thiers 2016). The distribution map of Agrostis scabra was created in Google Earth (Fig. 1). Approximate geographic coordinates were acquired using Google Earth (http://www. google.com/earth/download/ge/).

\section{TAXONOMIC TREATMENT}

Agrostis scabra Willd.

Sp. P1., ed. 4, 1(1): 370. 1797.

Perennial, caespitose. Culms 40-70 cm, erect, unbranched; nodes usually 4-5. Leaves (2nd from the top measured) $7-12 \mathrm{~cm}$ long, $1.2-2.3 \mathrm{~mm}$ wide, linear; adaxial surfaces deeply ribbed, scabrous; abaxial surfaces minutely scabrous. Sheaths usually smooth; collars smooth; ligules 4.3-4.8 mm long, truncate to acute, often lacerate. Panicle $20-33 \mathrm{~cm}$ long, broadly ovate in outline; branches in whorls of $2-7$, the lowest panicle branches $12-16 \mathrm{~cm}$ long; branches scabrous, capillary, flexible, wide-spreading, branching beyond middle, spikelets somewhat distant, not crowded, clustered at distal ends of branches; pedicels 0.7-8.0 mm long, scabrous. Spikelets $2.2-3.0 \mathrm{~mm}$ long, 1-flowered; glumes unequal, lanceolate, 1-veined, scabrid on keel, apices acuminate, the lower 2.2-3.0 $\mathrm{mm}$ long and $0.73-0.87 \mathrm{~mm}$ wide, the upper $1.9-2.5 \mathrm{~mm}$ long and $0.60-0.77 \mathrm{~mm}$ wide and 0.82-0.93 times as long as lower glume; callus hairs $0.2-0.3 \mathrm{~mm}$ long, $0.12-0.19$ times as 


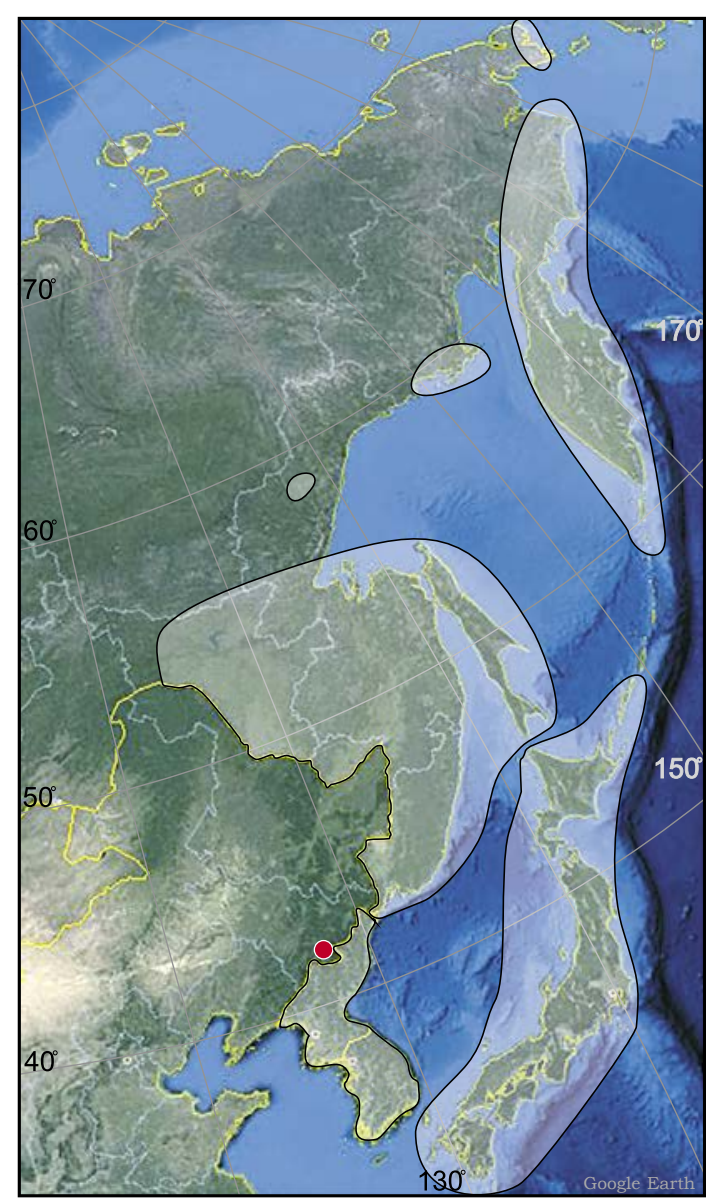

Fig. 1. Distribution of Agrostis scabra Willd. in East and Northeast Asia based on literature data (Ohwi 1965; Probatova 1985, 2006; Tzvelev 1976; Tzvelev \& Probatova 2012), with its first records (red dot, covers 4 localities) in the vicinity of Mt. Changbai (Jilin, northeast China).

long as lemmas, sparse; lemma 1.4-1.7 mm long, 5-veined, 0.56-0.67 times as long as lower glumes, apices acute to obtuse, usually entire, sometimes minutely toothed, unawned; palea $0.27-0.33 \mathrm{~mm}$ long, 0.18-0.23 times as long as lemmas. Anthers $0.36-0.50 \mathrm{~mm}$ long.

TaXonomic note. In China, Agrostis scabra can be misidentified as $A$. clavata. Both species are characterized by a tufted habit, short paleas, and usually awnless lemmas. Agrostis scabra differs from $A$. clavata by having longer ligules (4-5 mm vs. 0.5-4.0 mm long), and longer cal- lus hairs $(0.2-0.3 \mathrm{~mm}$ vs. often hairless, if hairy 0.05-0.2 mm long) (Paszko, unpubl.).

Distribution. Agrostis scabra was described by Carl Ludwig von Willdenow (1797: 370) based on a collection from North America. This species is native to Northeast Asia, North America and Greenland, and is naturalized in Germany and Austria (Tutin 2010). Agrostis scabra is known from the U.S.A., Canada, Greenland, Mexico, Japan, the Korean Peninsula, and Russia (Far East) (Harvey 2001, 2007; Ohwi 1965; Probatova 1985, 2003, 2006; Tzvelev 1976, 1984; Tzvelev \& Probatova 2012). A dot map provided by Probatova (1985, 2003) shows it to be common in the Russian Far East, with several dots along the Russian border with Heilongjiang and Jilin provinces of China, and North Korea.

The information about the distribution of A. scabra outside Russia given by Tzvelev (1976) is incorrectly translated in his English version (Tzvelev 1984). Both of them defined one of the regions as the Japan-China region, consisting of Japan, the Korean Peninsula and eastern regions of China. Tzvelev (1976) recorded the distribution of A. scabra only in two subregions of the JapanChina region: Japan and the Korean Peninsula. In the translated version (Tzvelev 1984) this information is translated as 'Japan, China (Korean Peninsula and Japan)', which is incorrect. This mistake does not refer only to A. scabra but also covers other species distributed in this region.

Agrostis scabra is not recorded in the most important treatments of Agrostis for the Chinese flora (Kitagawa 1979; Yang 1987; Qin 1995; Lu $\&$ Phillips 2006). However, in the earlier literature there are some notes about this species. Franchet (1884) recorded Agrostis laxiflora (Michx.) Richardson, nom. illeg. hom, (= A. scabra Willd.) from the vicinity of Pékin [French name for Beijing], based on the collection of Father Armand David no. 578. Rendle (in Forbes \& Hemsley 1904: 391) repeated this information but had not seen the specimen.

The core of Armand David's collection is housed at P, where David's collection (P 02244207) was located by the first author. A detailed revision 
showed that it represents $A$. clavata; therefore the record of Franchet (1884) and Rendle (in Forbes \& Hemsley 1904: 391) should be treated as a misidentification.

Kitagawa (1939) noted Agrostis scabra from Manchuria (in contemporary northeastern China) but without any details. In the revised version, Kitagawa (1979) did not record this species from this region. There is no further published specimen information reporting this particular species in China. Here we provide the first confirmed records from the vicinity of Mt. Changbai in Jilin Province, northeast China. We consider the Chinese occurrences to be part of the natural geographic range of the species.

Habitat. Agrostis scabra occurs throughout a wide variety of habitats: moist to dry meadows, rock outcrops, forest openings, clearings and roadsides in the lowland to subalpine zones (Harvey 2001, 2007; Matthews 2016). In Jilin it was collected in grassland and wet places between 900 and $1800 \mathrm{~m}$ a.s.l.

SPecimens EXAmined (Estimated geographic coordinates for localities are given in square brackets): CHINA. JiLIN [first records]: Antu Co., Shibei(?), Mt. Changbai, alt. $1800 \mathrm{~m},\left[42.16554^{\circ} \mathrm{N}, 128.06675^{\circ} \mathrm{E}\right]$, 30 July 1957, J.J. Qian 455 (KUN, PE); Fusong Co., hills near Manjiang town, wet place, alt. $900 \mathrm{~m}$, [41.94934 $\left.{ }^{\circ} \mathrm{N}, 127.587425^{\circ} \mathrm{E}\right], 24$ July 1957, J.J. Qian 274 (KUN, PE); Fusong Co., Huapihe to Manjiang, grassland, [41.94934 ${ }^{\circ} \mathrm{N}, 127.587425^{\circ} \mathrm{E}$ ], 28 July 1950 , M. Noda et al. 677 (KUN, PE); Fusong Co., Neidaoli to Wenquan, grassland, alt. $1700 \mathrm{~m},\left[42.161775^{\circ} \mathrm{N}\right.$, $\left.127.19893^{\circ} \mathrm{E}\right], 21$ July 1950, M. Noda et al. 430 (KUN, 2 sheets).

ACKNowledgements. Research visits of Beata Paszko in 2016 to herbaria in Beijing (PE) and Kunming (KUN) were supported by the exchange program between the Polish Academy of Sciences and the Chinese Academy of Sciences, and to Paris (P) by the SYNTHESYS Project, financed by the European Community Research Infrastructure Action under the FP7 'Capacities' Programme, grant FR-TAF-6137. This study was also financed in part from the statutory fund of the W. Szafer Institute of Botany of the Polish Academy of Sciences. We are grateful to Robert Soreng (Natural Museum of Natural History, Washington) for helpful remarks and suggestions on the manuscript.

\section{REFERENCES}

Forbes F. B. \& Hemsley W. B. 1904. An enumeration of all the plants known from China Proper, Formosa, Hainan, Corea, the Luchu Archipelago, and the Island of Hongkong, together with their distribution and synonymy. J. Linn. Soc., Bot. 36: $377-449$.

Franchet M. A. 1884. Plantae Davidianae ex Sinarum Imperio. Part 1. Plantes de Mongolie du nord et du centre de la Chine. G. Masson, Paris.

Harvey M. J. 2001. Agrostis. In: G. W. Douglas, Meidinger D. \& J. PoJAR (eds), Illustrated Flora of British Columbia 7. Monocotyledons (Orchidaceae through Zosteraceae), pp. 58-69. British Columbia Ministry of Sustainable Resource Management and Ministry of Forests, Victoria.

Harvey M. J. 2007. Agrostis L. In: M. E. Barkworth, K. M. Capels, S. Long, L. K. Anderton \& M. B. Piep (eds), Flora of North America, 24: 633-662. Oxford University Press, New York, Oxford.

Kitagawa M. 1939. Lineamenta Florae Manshuricae or an enumeration of all the indigenous vascular plants hitherto known from Manchurian Empire together with their synonymy, distribution and utility. Rep. Inst. Sci. Res. Manchoukuo 3(Appendix 1): 1-487.

Kitagawa M. 1979. Neo-Lineamenta Florae Manshuricae or enumeration of the spontaneous vascular plants hitherto known from Manchuria. J. Cramer, Vaduz.

Lu S. L. \& PhILliPs S. M. 2006. Agrostis Linnaeus. In: Z. Y. Wu, P. H. RAven \& D. Y. Hong (eds), Flora of China-Poaceae. 22: 340-348. Science Press, Beijing \& Missouri Botanical Garden Press, St. Louis.

Matthews R. F. 2016. Agrostis scabra. In: Fire Effects Information System [Online], U.S. Department of Agriculture, Forest Service, Rocky Mountain Research Station, Fire Sciences Laboratory (Producer). [9 Sept. 2016]. http:// www.fs.fed.us/database/feis/.

Nobis M., Ebel A. L., Nowak A., Turginov O. T., Kupriyanov A. N., Nobis A., Olonova M. V., Paszko B., Piwowarczyk R., Chen W. L., Gudkova P. D., KlichowSKa E., NowaK S. \& Pujadas-Salvà A. J. 2014. Contribution to the flora of Asian and European countries: new national and regional vascular plant records, 2. Acta Bot. Gallica 161(2): 209-221.

Nobis M., Nowak A., PiwowarczyK R., Ebel A. L., Király G., Kushunina M., Sukhorukov A. P., Chernova O. D., Kipriyanova L. M., Paszko B., Seregin A. P., ZalewskaGalosz J., Denysenko M., Nejfeld P., Stebel A. \& GudKOVA P. D. 2016. Contribution to the flora of Asian and European countries: new national and regional vascular plant records, 5. Botany Letters 163(2): 159-174.

Oнwi J. 1965. Flora of Japan. A combined, much revised, and extended translation by the author of his Flora of Japan (1953) and Flora of Japan - Pteridophyta (1957). Smithsonian Institution, Washington, D.C. 
Paszko B. 2012. Taxonomic revision of Calamagrostis filiformis, C. tripilifera and their allies (Poaceae: Agrostidinae). Polish Bot. J. 57(2): 335-346.

Paszko B. 2014a. Agrostis pendryi (Poaceae: Agrostidinae) - a new species from the Central Himalaya. Phytotaxa 175(1): 29-36.

PaszKo B. 2014b. Agrostis schischkinii, a new name for Agrostis trichantha (Schischk.) Tzvelev (Poaceae, Agrostidinae). Phytotaxa 170(2): 136-138.

Paszko B. \& Pendry C. A. 2013. Agrostis griffithiana (Poaceae: Agrostidinae) - typification, a new synonym and an update of the distribution in India. Phytotaxa 140(1): 26-34.

Paszko B. \& Soreng R. J. 2013. Species delimitation and name application in Deyeuxia abnormis, Agrostis zenkeri, A. pleiophylla and related taxa (Poaceae: Agrostidinae). Phytotaxa 111(1): 1-26.

Paszko B., Pendry C. A., Kar S. \& Singh P. 2015. Typification of Hooker's name Calamagrostis munroana var. stricta (Poaceae, Agrostidinae). Phytotaxa 203(1): 69-75.

Probatova N. S. 1985. Poaceae. In: N. N. Tzvelev (ed.), Sosudistye rasteniya sovetskogo Dalnego Vostoka. 1: 89-382. Nauka, Leningrad.

Probatova N. S. 2003. Poaceae. In: N. N. Tzvelev (ed.), Vascular plants of the Soviet Far East, 1: 89-488. Translated from Russian by I. Sokolova. Science Publishers, Enfield, USA \& Plymouth, UK.

Probatova N. S. 2006. Calamagrostis Adans. In: N. S. ProBATOVA \& A. E. KozHEVNikov (eds), Flora of the Russian
Far East. Addenda and corrigenda to "Vascular plants of the Soviet Far East" Vol. 1-8 (1985-1996), pp. 333-337. Dalnauka, Vladivostok.

QIN Z. S. 1995. Agrostis L. In: P. Y. Fu (ed.), Clavis plantarum Chinae boreali-orientalis. $2^{\text {nd }}$ ed., p. 799. Scientific Publishing House, Beijing.

THIERS B. 2016 [continuously updated]. Index herbariorum: a global directory of public herbaria and associated staff. New York Botanical Garden's virtual herbarium. [15 Aug. 2016]. http://sweetgum.nybg.org/science/ih/.

Tutin T. G. 2010. Agrostis L. In: T. G. Tutin, V. H. HeYwood, N. A. Burges, D. M. Moore, D. H. Valentine, S. M. Walters \& D. A. Webb (eds), Flora Europaea. 5: 232-235. Cambridge University Press, Cambridge.

Tzvelev N. N. 1976. Zlaki SSSR. Nauka, Leningrad.

Tzvelev N. N. 1984. Grasses of the Soviet Union. 2 vols. Translated from Russian by B. R. Sharma. A. A. Balkema, Rotterdam.

Tzvelev N. N. \& Probatova N. S. 2012. The taxonomic revision of the genera Deschampsia, Agrostis, Calamagrostis (Poaceae: Poeae) and the system of grasses in the flora of Russia. Komarovskie Chteniya (Vladivostok) 59: 7-75 (in Russian).

WiLldenow C. L. 1797. Species plantarum.1(1). Ed. 4. G. C. Nauk, Berolinum.

YAng Y. C. 1987. Agrostis L. In: P. C. Kuo (ed.), Flora Reipublicae Popularis Sinicae. 9(3): 229-251. Science Press, Beijing. 